STUDIA PRAWNO-EKONOMICZNE, T. CXII, 2019

PL ISSN 0081-6841; e-ISSN 2450-8179 $\quad$ s. 225-239

https://doi.org/10.26485/SPE/2019/112/13

Joanna DZIAŁO*

iD https://orcid.org/0000-0001-8132-8101

\title{
INSTITUTIONAL BORROWING RESTRICTIONS: EVIDENCE FROM POLISH LOCAL GOVERNMENTS
}

\begin{abstract}
(Summary)
Municipal borrowing is a financial mechanism that enables local governments to pass tax burdens on to future generations. The theory of public finance argues that local government borrowing and spending may be more than optimal if the decisions of politicians are aimed at political gains. Therefore, the need for restrictions on borrowing by local governments is a generally accepted notion that is justified also by the fact that such restrictions are in force in the majority of decentralized countries. This paper is concerned with the debt level of Polish municipalities from 1990 to 2017. The main objective is to present past trends in the policies adopted in Poland concerning the mandatory limitations on municipal borrowing. Additionally, the author will try to assess the effectiveness of mandatory borrowing constraints and check whether current legislation takes into account the theoretical arguments of borrowing constraints.
\end{abstract}

Keywords: public debt; local borrowing; local governments; debt limits

Classification JEL: H60, H63, H74

\section{Introduction}

Subnational borrowing is a financial mechanism that enables local governments to pass their tax burdens onto future generations. Within the context of the public choice theory of fiscal illusion (debt illusion), local government borrowing and spending may be suboptimal if the decisions of politicians and bureaucrats are aimed exclusively at political gain. In other words, if their intention is to maximize the number of votes captured, they increase the provision of goods and services without raising the taxes needed to finance them, leaving the burden to future governments. As a consequence, voters systematically overestimate the benefits of deficit-financed government expenditures today while underestimating future

* Professor, Lazarski University, Warsaw; e-mail: joanna.dzialo@lazarski.pl 
tax liabilities due to public debt. The literature on fiscal federalism also presents various arguments in favor of the enforcement of subnational government borrowing restrictions: intergenerational equity, the preservation of long-term financial stability, and the coordination of fiscal policy by central governments. As a result, decentralization may be associated with the growing indebtedness of local governments, and costlier borrowing at the central and subnational levels. The aim of the paper is to discover whether the legal constraints on municipal borrowing introduced over the study period (1990 to 2017) in Poland were effective in imposing some degree of financial discipline on borrowing policies.

\section{The main drivers of sub-central government debt}

According to the public finance literature, local government (LG) deficit and debt have the following main causes:

- A structural mismatch between LG spending obligations and the allocation of revenues. Sub-central deficits and debts may be the result of improper fiscal relations between levels of government, where the revenues obtained by LGs are insufficient to cover their expenditure responsibilities.

- Economic downturns can generate temporary sub-central deficits and debts. While LG spending obligations tend to be stable over the economic cycle, their revenues are usually pro-cyclical (decreasing during recessions), which causes deficits and debts.

- LGs may be subject to soft budget constraints and moral hazard, causing them to overspend and issue debt in the expectation that upper-tier government will increase transfers to them or bail them out in the event of financial difficulty.

- Local governments use external sources of finance to raise funds for investment projects. In the case of EU countries, a particular motivation may be to participate in development projects funded by the Cohesion Policy of the European Union. For example, local debt in East-Central Europe is often associated with the local government's participation in EU-funded projects. Being successful at obtaining EU funding for projects leads to higher levels of local debt ${ }^{1}$.

Local government debt policy is important to monitor and manage for a number of reasons. First, debt creates externalities across levels of government.

P. McCann, A. Varga, The Reforms to the Regional and Urban Policy of the European Union: EU Cohesion Policy, Regional Studies 2015/49: 8, pp. 1255-1257. 
Increases in debt by one part of the government may increase general government debt, thereby affecting budget balances and potentially interest rates on public debt. Second, the risk of contagion can disrupt financial markets. Spreading fear of a general "disease" at the local level may become self-fulfilling and cause problems for all LGs to access private financing at sustainable interest rates. Finally, in most countries, the central government takes political responsibility for LG debt, often via bailout guarantees. LGs expecting a bailout may engage in irresponsible and risky fiscal policy, thereby increasing general government debt ${ }^{2}$. Central government must cope with a number of challenges when monitoring LG debt. They include ${ }^{3}$ :

- The scarcity of appropriate, timely information on LG financial and debt situations. Budget documents and data should be open, transparent, and accessible 4 .

- Lack of believability and low compatibility of local financial information.

- Lack of bankruptcy procedures specifically for local governments. Instead, the central government intervenes directly, often with discretionary grants, to support them. Bailout expectations may have serious consequences, as creditors may consider that local debt is implicitly guaranteed by the central government. Consequently, they continue to lend to local governments, which finally leads to higher debt $^{5}$.

\section{The main strategies for controlling subnational debt}

Despite the aforementioned challenges, most central governments monitor local government debt. National approaches to the control of LG debt can be grouped into four categories ${ }^{6}$ :

- $\quad$ Market-based discipline;

- Direct debt control (by central government);

Fiscal Federalism 2014: Making Decentralisation Work, OECD Publishing, Paris 2014 (d).

B. Rigaud, P.-E. Arsenault, Budget Governance in Canada: Comparing Practices within a Federation, OECD Journal on Budgeting 2013/1, OECD, Paris, pp. 24-43.

4 C. Vammalle, R. Ahrend, C. Hulbert, A Sub-national Perspective on Financing Investment for Growth II - Creating Fiscal Space for Public Investment: The Role of Institutions, OECD Regional Development Working Papers 2014/06, OECD Publishing, Paris.

5 M. Baltaci, S. Yilmaz, Keeping an Eye on Sub-central Governments: Internal Control and Audit at Local Level, International Bank for Reconstruction and Development/World Bank 2006, pp. 14-29.

6 T. Ter-Minassian, J. Craig, Control of sub-national government borrowing, in: T. Ter-Minassian (ed.), Fiscal Federalism in Theory and Practice, IMF 1997, pp. 87-103. 
- Rules-based control (especially debt limits);

- Cooperation by different levels of government.

In the context of market-based discipline, banks assess the creditworthiness of LGs that wish to borrow or issue debt. They then impose higher borrowing costs on the riskier ones. For market discipline to work, a number of conditions need to be satisfied. Markets should be open and financially deep, and they should afford no privileges to LG debt. Appropriate information about the borrower's outstanding debt and re-payment capacity should be available to potential lenders, and the central government's no-bailout commitment should be credible. Recognition of these realities may be a major reason why sole reliance on market discipline to check subnational government borrowing is not usual ${ }^{7}$.

In a number of countries, the central government is empowered with direct control over the borrowing of local governments. This control may take various forms, including the setting of annual limits on the overall debt of individual LGs (or some of its components, such as external borrowing), the prohibition of some borrowing, the review and authorization of individual borrowing operations and/or the centralization of all government borrowing, with on-lending to local governments for approved purposes (generally investment projects). Some arguments exist in favor of direct central government control. First, debt policy is linked with other macroeconomic policies (like monetary and exchange rate policies), which are the responsibility of central-level authorities. Second, a deterioration of foreign ratings for one or more of the local governments may have contagion effects on the ratings for other borrowers. Third, lenders frequently require an explicit central government guarantee for subnational local borrowing. Thus, the central government bears the ultimate responsibility for the local governments' debt. Direct central government control seems highly effective in monitoring LG debt. There are two main drawbacks, however. First, it may be perceived by lenders as an implicit bailout guarantee in case of an LG default, and thus favors moral hazard. Second, central governments may not have the appropriate information to assess LG spending when deciding which ones to finance. This approach to debt control postulates the active role of local governments in formulating macroeconomic and fiscal parameters (e.g., revenues, expenditures, deficit, etc.) to be reached ${ }^{8}$.

C. Vammalle, C. Hulbert, Sub-national Finances and Fiscal Consolidation: Walking on Thin Ice, OECD Regional Development Working Papers 2013/02, pp. 34-50.

8 R.J. Singh, A. Plekhanov, How Should Subnational Borrowing be Regulated? Empirical Evidence from a Cross-Country Study, IMF Working Paper, no. 54, International Monetary Fund, Washington DC 2005. 
Fiscal rules are an alternative to direct monitoring. There are three main types: budget balance rules, expenditure ceilings, and borrowing limits. The most common in OECD and EU countries is the budget balance rule. Borrowing constraints, for example, on the level of debt or debt service, are also frequently used. Many LGs are also subject to a golden rule, which means that the government should borrow money only to fund investments that will benefit future generations, while current spending must be covered by existing taxes. Direct expenditure limits are less frequent ${ }^{9}$. Although sub-central fiscal rules have long been in place in many countries, the financial crisis of 2007 spurred them to tighten their rules. However, the impact of fiscal rules on LG debt is subject to debate. Tight fiscal rules are designed to save governments from overindebtedness, but the empirical evidence as to whether they do so is mixed. Some older studies find that balanced budget rules reduce budget deficits ${ }^{10}$. Other studies conclude that fiscal rules do not play a prominent role in ensuring better fiscal performance ${ }^{11}$. The rules-based approach has the obvious advantage of transparency, uniformity, and ease of monitoring. On the other hand, it lacks flexibility and often ends up fostering the development of behavior and practices aimed at circumventing the rules. This is particularly about the reclassification of certain categories of expenditure, e.g., from current to investment, transfer of certain activities along with incurring debt to companies belonging to local government units or the use of specific instruments and methods of debt (for example public-private partnership) the limit of which does not apply. This suggests that, to be effective, a rules-based approach needs to be supported by clear and uniform accounting standards for government entities.

Under the cooperation by different levels of government approach, limits on the indebtedness of local governments are not set by law or dictated by the center but are arrived at through a negotiation process between the central and the lower levels of government. The cooperative approach has advantages in promoting dialogue and the exchange of information across various government levels. It also raises the consciousness of local policymakers of the macroeconomic implications of their budgetary choices. It seems, however, to work best in

9 Fiscal Federalism...

10 J. Poterba, State Responses to Fiscal Crisis: The Effects of Budgetary Institutions and Politics, Journal of Political Economy 1994/102 (4), pp. 799-821; H. Bohn, R.P. Inman, Balanced budget rules and public deficits: Evidence from the U.S. States, NBER Working Paper 1996/5533.

${ }^{11}$ J. Escolano, L. Eyraud, M. Moreno Badia, J. Sarnes, A. Tuladhar, Fiscal performance, institutional design and decentralization in European Union countries, IMF 2012. 
countries with an established culture of fiscal discipline. It may not be effective in preventing a build-up of debt in conditions where either market discipline or the leadership of the central government are weak ${ }^{12}$.

\section{The evolution of municipal borrowing restrictions in Poland}

Having completed a brief overview of municipal debt patterns, there is a need to present the evolution of the existing institutional restrictions in Polish municipal regulations. Which of the above strategies have been selected by Polish legislation to deal with municipal debt? Municipal debt in Poland has been systematically growing since the mid-1990s (see Table 1 and Table 2). Definitely, one of the main reasons for the rapid growth of municipal debt was the financial crisis of $2008 / 2009$. However, there is one more factor worth mentioning that greatly affected the growing indebtedness of Polish municipalities: the decentralization of public finance, which started at the beginning of the 1990s.

In the case of fiscal federalism, the question always arises: how much fiscal autonomy should local governments have? On the one hand, the complete centralization of fiscal authority cannot be optimal. On the other hand, fully decentralized fiscal policy is inefficient as well. However, in between these two extremes, there are many choices for countries to make. Among the arguments against too much local fiscal autonomy, a prominent one is that fiscal decentralization exacerbates budgetary problems. First, local tax autonomy could result in tax competition and inefficiently low levels of taxation ${ }^{13}$. Additionally, if local governments are not able to reduce expenditures in response to declining tax revenues, tax competition might lead to higher deficits and more debt. Second, local expenditure autonomy may result in over-borrowing if lowerlevel governments do not fully internalize the social costs of debt. For example, if a local government anticipates a bailout (it expects that the central government will eventually cover a fraction of its debt), it will face strong incentives to overborrow ${ }^{14}$. Third, it is more difficult to pursue specific budgetary goals if the

12 T. Ter-Minassian, Fiscal rules for subnational governments: Can they promote fiscal discipline?, OECD Journal on Budgeting 2007/6 (3), pp. 1-11.

13 J.D. Wilson, A theory of interregional tax competition, Journal of Urban Economics 1986/19 (3), pp. 296-315; G.R. Zodrow, P. Mieszkowski, Pigou, Tiebout, property taxation and the under-provision of local public goods, Journal of Urban Economics 1986/19 (3), pp. 356-370.

14 T.J. Goodspeed, Bailouts in a federation, International Tax and Public Finance 2002/9 (4), pp. 409-421; D. Wildasin, Externalities and bailouts: hard and soft budget constraints in intergovernmental fiscal relations, World Bank Policy Research 1997, Working Paper No. 1843. 
public sector is decentralized. Since the budgetary targets usually refer to the general government, both the central and all local governments are responsible for achieving them. Yet it is typically the central government that has to bear the blame if the target is missed ${ }^{15}$. In view of this political reality, local governments might have few incentives to pursue painful austerity measures. Summing up, the literature on fiscal federalism presents basic arguments in favour of the enforcement of local government borrowing restrictions: intergenerational equity, the preservation of long-term financial equilibrium, and the coordination of fiscal policy by central governments.

TABLE 1: Municipal debt in Poland, bn PLN

\begin{tabular}{|c|c|c|c|c|c|c|c|c|c|c|c|c|}
\hline Year & $\mathbf{1 9 9 5}$ & $\mathbf{1 9 9 6}$ & $\mathbf{1 9 9 7}$ & $\mathbf{1 9 9 8}$ & $\mathbf{1 9 9 9}$ & $\mathbf{2 0 0 0}$ & $\mathbf{2 0 0 1}$ & $\mathbf{2 0 0 2}$ & $\mathbf{2 0 0 3}$ & $\mathbf{2 0 0 4}$ & $\mathbf{2 0 0 5}$ & $\mathbf{2 0 0 6}$ \\
\hline Debt & 1.9 & 3.4 & 7.1 & 7.0 & 8.2 & 9.9 & 13.2 & 17.9 & 19.8 & 21.9 & 24.9 & 28.4 \\
\hline Year & $\mathbf{2 0 0 7}$ & $\mathbf{2 0 0 8}$ & $\mathbf{2 0 0 9}$ & $\mathbf{2 0 1 0}$ & $\mathbf{2 0 1 1}$ & $\mathbf{2 0 1 2}$ & $\mathbf{2 0 1 3}$ & $\mathbf{2 0 1 4}$ & $\mathbf{2 0 1 5}$ & $\mathbf{2 0 1 6}$ & $\mathbf{2 0 1 7}$ & $\mathbf{2 0 1 8}$ \\
\hline Debt & 29.3 & 32.1 & 45.2 & 52.0 & 64.9 & 67.7 & 69.1 & 72.1 & 71.5 & 69.0 & 68.9 & n.a. \\
\hline
\end{tabular}

S o u r c e: own elaboration, data supplied by the Central Statistical Office in Poland.

TABLE 2: Municipal debt in Poland (share in total municipal income, \%)

\begin{tabular}{|l|c|c|c|c|c|c|c|c|c|c|c|c|}
\hline Year & $\mathbf{1 9 9 5}$ & $\mathbf{1 9 9 6}$ & $\mathbf{1 9 9 7}$ & $\mathbf{1 9 9 8}$ & $\mathbf{1 9 9 9}$ & $\mathbf{2 0 0 0}$ & $\mathbf{2 0 0 1}$ & $\mathbf{2 0 0 2}$ & $\mathbf{2 0 0 3}$ & $\mathbf{2 0 0 4}$ & $\mathbf{2 0 0 5}$ & $\mathbf{2 0 0 6}$ \\
\hline $\begin{array}{l}\text { Share } \\
\text { of debt }\end{array}$ & 8.9 & 10.1 & 13.8 & 10.9 & 9.9 & 13.7 & 15.0 & 18.9 & 22.4 & 21.2 & 20.8 & 21.9 \\
\hline Year & $\mathbf{2 0 0 7}$ & $\mathbf{2 0 0 8}$ & $\mathbf{2 0 0 9}$ & $\mathbf{2 0 1 0}$ & $\mathbf{2 0 1 1}$ & $\mathbf{2 0 1 2}$ & $\mathbf{2 0 1 3}$ & $\mathbf{2 0 1 4}$ & $\mathbf{2 0 1 5}$ & $\mathbf{2 0 1 6}$ & $\mathbf{2 0 1 7}$ & $\mathbf{2 0 1 8}$ \\
\hline $\begin{array}{l}\text { Share } \\
\text { of debt }\end{array}$ & 19.8 & 20.2 & 25.3 & 31.9 & 37.1 & 38.2 & 39.1 & 41.3 & 40.9 & 38.1 & 37.8 & n.a. \\
\hline
\end{tabular}

S o u r c e: own elaboration, data supplied by the Central Statistical Office in Poland.

Therefore, there was an urgent need to control the level of the LGs' debt in Poland. Over the investigation period, there have been several modifications to the rules for controlling borrowing at the local level. In 1990, the Local Government Act introduced regulations in which short-term loans in each local government could not exceed 5\% of the planned expenditures in the budget

I. Joumard, P.M. Kongsrud, Fiscal relations across government levels, OECD Economic Studies 2003/36 (1), pp. 155-229. 
year $^{16}$. Concurrently, the debt could not exceed $8 \%$ of the planned annual expenditure in the first half of the year and 4\% in the second half. In 1999 , important amendments were implemented; the LG could take loans and credits or issue securities to finance budgetary shortages within a year. Additionally, the total debt at the end of the year could not be higher than $60 \%$ of revenues. What is more, the total debt, which had to be paid in the budgetary year, could not exceed $15 \%$ of the planned revenues or $12 \%$ if the public debt to GDP was higher than $55 \%{ }^{17}$. Since 2011, in Poland, it is forbidden to enact a local budget in which planned current expenditures exceed expected current revenues with the budget surplus from previous years (a ban on borrowing to cover current expenditures). Therefore, the growth of the debt does not result from the deficit in the current part of the budget ${ }^{18}$. This means that the limits on debt were uniform for all local governments, and therefore, it raised criticisms among the representatives of local governments as they did not take into account the financial condition of particular LGs. However, during the period covered by these regulations, i.e., until 2013, a continuous increase in local government debt was observed. In the years 1999-2013, it increased from PLN 8.2 billion to PLN 69.1 billion, which contributed to the increase in its share in GDP from $0.9 \%$ to $4.2 \%$. It is pointed out that a significant increase in these shares resulted from the incurrence of debt related to the absorption of EU funds by these entities ${ }^{19}$.

However, the crucial regulation was implemented in $2014^{20}$. The new rule was designed in order to prevent local government debt repayment difficulties. As a result, debt limitation is estimated separately for each local government (an individual debt limit - IDL). According to new regulations, local governments cannot adopt a budget in which the relationship resulting from the formula for an IDL is not maintained.

The individual debt limit has the following formula ${ }^{21}$ :

$$
\left(\frac{P+I}{R}\right) \leq \frac{1}{3} \frac{(C B+A S)_{t-1}}{R_{t-1}}+\frac{(C B+A S)_{t-2}}{R_{t-2}}+\frac{(C B+A S)_{t-3}}{R_{t-3}}
$$

16 Ustawa z dnia 8 marca 1990 r. o samorządzie terytorialnym (1990a), Dz.U. z 2017 r., poz. 1875 z późn. zm.

17 Ustawa z dnia 26 listopada 1998 r. o finansach publicznych, Dz.U. nr 155, poz. 1014 z późn. zm.

18 Ustawa z dnia 30 czerwca 2005 r. o finansach publicznych, Dz.U. nr 249, poz. 2104 z późn. zm.

19 G. Medve-Bálint, D. Bohle, Local Government Debt and EU Funds in the Eastern Member States: The Cases of Hungary and Poland, MAXCAP Working Paper Series 2016/33, p. 22.

20 Ustawa z dnia 27 sierpnia 2009 r. o finansach publicznych, Dz.U. z 2017 r., poz. 2077.

${ }^{21}$ Ibidem. 
where:

$t$ - year for which the indicator is calculated;

$P$ - principal installments; $I$ - interest payments, discounts, etc.;

$R$ - total revenues;

$C B$ - current balance;

$A S$ - asset sale proceeds.

The value of the index depends on the size of income earned by the local government, on the income amount received from the sale of property, as well as on the scale of expenditures on current operations. A three-year average ratio of current balance and asset sales to revenues serves as a kind of proxy for the debt repayment ability. It is worth remembering that the current balance is subject to another fiscal rule (mentioned earlier), according to which current revenues together with budget surpluses from the past and free financial sources have to cover all current expenditures. It is assumed that it should diminish the propensity for asset sales in order to satisfy the new debt repayment rule. The general idea is that the generated indebtedness should result from the investment activity of the municipality. The index is designed to optimize the LGs' debt accrual.

Some economists state that the index is not a favorable solution for all local governments. Criticism concerns the following issues ${ }^{22}$ :

- Calculations based on historical data, which may not reflect the current financial situation of local government units;

- The method for calculating operating surplus to total revenue;

- It is impossible for LGs to borrow in situations where they have not reached an operating surplus: the creation of debt capacity at the expense of communal property sales. This threat is partially eliminated by a legal requirement to balance current revenues and current expenditures. Still, a current surplus may turn out to be insufficient in comparison to debt repayments ${ }^{23}$;

- The need to offset expenses related to the debt for the following years, the consequence of which is an increase in costs and the accumulation of fixed expenses in subsequent years;

- The dependency of the index on many variables, obstructing its planning and implementation.

22 A. Czarny, Limity zadlużenia jednostek samorzadu terytorialnego na przykładzie powiatów województwa zachodniopomorskiego, Folia Pomeranae Universitatis Technologiae Stetinensis. Oeconomica 2015/80, pp. 27-36.

23 K. Wójtowicz, Zalety $i$ wady obowiązującego systemu limitowania deficytu $i$ dhugu samorzadowego w Polsce, Annales Universitatis Mariae Curie-Skłodowska. Sectio H. Oeconomia 2013/47 (2), pp. 153-161. 
However, there are also some advantages to an IDL. The legislator, by constructing a new index, aimed to remove barriers that restrict local government that have considerable economic potential in a situation where incurring additional obligations would not constitute a financial threat. Thus, it is an instrument that allows for a departure from "rigid" limits that do not reflect the actual credit abilities of local governments. For these LGUs, the index is a tool for safe development. On the other hand, the index should ensure that local governments with a high financial burden proceed with caution when taking on new credit and loans ${ }^{24}$.

As a consequence of the limit, in the 2014-2017 period, a decline in the level of local government debt from PLN 72.1 billion to PLN 68.9 billion was observed (and in relation to GDP, from $4.2 \%$ to 3.6\%). However, despite this decrease, some communes revealed a very high level of debt in relation to total revenues, as much as $284 \%$ or $269 \%{ }^{25}$. At the same time, the local government debt in non-bank financial institutions (para-banks) increased from PLN 105 billion in 2013 to PLN 164 billion in 201726. Therefore, the use of non-standard operations in the process of incurring debt became a threat. These operations include leaseback agreements, reverse sale agreements for real estate, various types of contracts causing debt restructuring, e.g., assignment of receivables, subrogation, forfeiting, factoring, as well as installment payments, and equity financing of municipal companies (subsidies for capital) ${ }^{27}$.

Finally, regarding some other mechanisms implemented in Poland to support the effectiveness of public finance management at the local level, worthy of note are the following factors:

- Performance budget;

- Long term finance forecast of the LGs.

Performance budgeting. The budget system in its traditional structure is the most common form of budget used by local governments in Poland. This type of budgeting focuses on goods and services to be purchased. Unfortunately, such budget systems are not transparent and do not provide comprehensive information on the rational and effective management of financial resources. Therefore, local governments have to gradually implement a new financial

24 A. Czarny, op. cit.

25 Wpływ operacji finansowych stosowanych przez wybrane jednostki samorzadu terytorialnego na ich sytuacje finansowa, NIK, Warszawa 2016.

26 M. Cyrankiewicz, Trwa spór o wskaźnik zadtużenia, Rzeczpospolita 2017/102.

27 P. Galiński, Limitowanie dtugu jednostek samorzadu terytorialnego w Polsce, Zarządzanie i Finanse 2017/2/2, pp. 19-31. 
management tool: the performance budget. Basing their planning on the task oriented budget, local governments depart from the traditional method of recording income and expenses, to turn toward a system that puts emphasis on results and effects and on the scope of what has been achieved. Performance budgeting in Poland was introduced at the central level of government in 2009 , but it has been in existence at the local government level since $1994^{28}$. Its objective is to increase the transparency of public spending, its rationality, and the effectiveness of public finance management. Because of performance budgeting, the following results can be achieved ${ }^{29}$ :

- Linking the allocation of funds to clearly expressed expectations;

- Establishing procedures that cause decisions about the distribution of funds to be transparent and clear;

- Allocating responsibilities for particular tasks among specific individuals within local government structures and developing mechanisms and status reports to monitor the performance of tasks in relation to the expected results;

- Developing mechanisms to assess results in order to monitor the effectiveness of spending in a given activity or program.

The second instrument (the Long Term Financial Forecast of the LGU) was introduced in the Public Finance Act of 2009 and was made mandatory for local governments for the first time in $2011^{30}$. It allows for a look at government finances over the next few years in order to plan the socioeconomic development of the local government. Its role is to increase efficiency, transparency, openness, and predictability in the accumulation of income, revenues, and expenses ${ }^{31}$. Contemporary long-term planning is seen as a necessary condition for the proper management of public finances. Its purpose in local governments is to determine the possibilities for financing current and investment tasks from their own resources and from external sources, and the appropriate correlation between the annual budget and long-term objectives ${ }^{32}$.

28 S. Owsiak, Budżet władz lokalnych. Narzędzie zarządzania, PWE, Warszawa 2002.

29 D. Bartkowska-Nowak, J. Nowak, J. Webb, Zarządzanie w gminie. Podręcznik doskonalenia umiejętności kierowniczych, Brytyjski Fundusz Know-How, Warszawa 1998.

30 Ustawa z dnia 27 sierpnia 2009 r. o finansach publicznych, Dz.U. z 2017 r., poz. 2077.

31 K. Owsiak, Wieloletnia prognoza finansowa jako instrument zarzadzania finansami jednostek samorzadu terytorialnego, Zeszyty Naukowe Uniwersytetu Ekonomicznego w Katowicach 2014/198, pp. 166-176; M. Jóźwiak, P. Walczak, U. Wiktorowska, Wieloletnia prognoza finansowa. Sporzadzanie i uchwalanie, Municipum, Warszawa 2010.

32 C. Kosikowski, Naprawa finansów publicznych w Polsce, Temida, Białystok 2011. 


\section{Concluding remarks}

The review of selected forms of control on local government borrowing shows that the nature and coverage of these forms vary significantly. They reflect the individual country's history, macroeconomic conditions, the balance of power among the different levels of government, and the state of development of financial markets. Each of the "models" of control analyzed in the paper presents advantages and disadvantages, the balance of which would make it more or less suitable to a particular country's circumstances. Moreover, as these circumstances evolve, for example, as the macroeconomic situation improves or worsens, the preferable model may change over time.

From the review of Poland's experiences, it appears that reliance on market discipline for government borrowing is not appropriate because the conditions for its effective working are not realized in the country. However, market discipline can be a useful complement to other forms of borrowing controls under the condition of greater transparency and dissemination of information on recent and prospective developments in the finances of local governments. The system of direct controls by the central government on local borrowing (involving, for example, the approval of individual loan operations or setting the annual level of debt) is not popular in Poland. One of the reasons could be the shortage of appropriate information to assess LG spending by the central government. Additionally, the central government may be afraid that such control may be perceived by local governments as a bailout guarantee in case of an LG default. A rules-based approach to debt control appears preferable in Poland in terms of transparency and certainty. The system is based on designated limits constructed using data from the budgets of particular LGs. After 1990, the system was subject to numerous modifications, and the solutions in place since 2014 take into account the ability of the individual local government to repay its debt to a greater extent. It has to be mentioned that the introduction of an individual debt ratio revealed the problem of hiding the LGs' debt. In addition, the indebtedness of these units in para-banks increased, which means that the intentions of the legislator in the context of debt limitation are bypassed. This, in turn, may determine an increase in the risk of losing LGs liquidity and their insolvency.

Finally, even in the context of the rules-based approach, there seems to be scope for increased cooperation of all levels of government in containing the growth of public debt. Currently, such cooperation is very limited in Poland. Enhanced involvement of the local governments in formulating and implementing 
medium-term fiscal adjustment programs should result in these governments becoming more responsible in the conduct of their budgetary affairs. Effective political and intellectual leadership by the central government remains essential and may be viewed as the natural evolution of the traditional administrative controls in an increasingly decentralized world.

\section{References}

\section{Legal Acts}

Ustawa z dnia 8 marca 1990 r. o samorządzie terytorialnym (Dz.U. z 1990 r., poz. 1875 z późn. zm.). Ustawa z dnia 26 listopada 1998 r. o finansach publicznych (Dz.U. z 1998 r. nr 155, poz. 1014 z późń. zm.).

Ustawa z dnia 30 czerwca 2005 r. o finansach publicznych (Dz.U. z 2005 r. nr 249, poz. 2104 z późń zm.).

Ustawa z dnia 27 sierpnia 2009 r. o finansach publicznych (Dz.U. z 2017 r., poz. 2077).

\section{Books/Articles}

Baltaci Mustafa, Yilmaz Serdar, Keeping an Eye on Sub-central Governments: Internal Control and Audit at Local Level, International Bank for Reconstruction and Development: World Bank 2006.

Bartkowska-Nowak Dobrochna, Nowak Jacek, Webb John, Zarządzanie w gminie. Podręcznik doskonalenia umiejętności kierowniczych, Brytyjski Fundusz Know-How, Fundusz Współpracy, Warszawa 1998.

Bohn Hennig, Inman Robert P., Balanced budget rules and public deficits: Evidence from the U.S. States, NBER Working Paper 1996/5533.

Cyrankiewicz Michal, Trwa spór o wskaźnik zadlużenia, Rzeczpospolita 2017/102.

Czarny Anna, Limity zadlużenia jednostek samorządu terytorialnego na przykładzie powiatów województwa zachodniopomorskiego, Folia Pomeranae Universitatis Technologiae Stetinensis. Oeconomica 2015/80.

Escolano Julio, Eyraud Luc, Moreno Badia Marialuz, Sarnes Juliane, Tuladhar Anita, Fiscal performance, institutional design and decentralization in European Union countries, IMF Working Papers 2012/12/45.

Fiscal Federalism: Making Decentralisation Work, OECD 2014.

Galiński Pawel, Limitowanie dtugu jednostek samorządu terytorialnego w Polsce, Zarządzanie i Finanse 2017/2/2.

Joumard Ian, Kongsrud Peter, Fiscal relations across government levels, OECD Economic Studies 2003/36 (1), pp. 155-229.

Jóźwiak Małgorzata, Walczak Piotr, Wiktorowska Urszula, Wieloletnia prognoza finansowa. Sporzadzanie i uchwalanie, Municipium, Warszawa 2010.

Kosikowski Cezary, Naprawa finansów publicznych w Polsce, Temida, Białystok 2011.

McCann Philip, Varga Attila, The Reforms to the Regional and Urban Policy of the European Union: EU Cohesion Policy, Regional Studies 2015/49/8. 
Medve-Bálint Gergo, Bohle Dorothee, Local Government Debt and EU Funds in the Eastern Member States: The Cases of Hungary and Poland, MAXCAP Working Paper Series 2016/33.

Owsiak Katarzyna, Wieloletnia prognoza finansowa jako instrument zarzadzania finansami jednostek samorzadu terytorialnego, Studia Ekonomiczne. Zeszyty Naukowe Uniwersytetu Ekonomicznego w Katowicach 2014/198.

Owsiak Stanisław, Budżet władz lokalnych. Narzędzie zarządzania, PWE, Warszawa 2002.

Poterba James, State Responses to Fiscal Crisis: The Effects of Budgetary Institutions and Politics, Journal of Political Economy 1994/102 (4).

Rigaud Benoit, Arsenault Paul-Emile, Budget Governance in Canada: Comparing Practices within a Federation, OECD Journal on Budgeting 2013/1, OECD, Paris.

Singh Raju J., Plekhanov Alexander, How Should Subnational Borrowing be Regulated? Empirical Evidence from a Cross-Country Study, IMF Working Paper, no. 54, International Monetary Fund, Washington DC 2005.

Ter-Minassian Teresa, Fiscal rules for subnational governments: Can they promote fiscal discipline?, OECD Journal on Budgeting 2007/6 (3).

Ter-Minassian Teresa, Craig James, Control of Subnational Government Borrowing, in: Teresa Ter-Minassian (ed.), Fiscal Federalism in Theory and Practice, International Monetary Fund, Washington D.C. 1997.

Theodore Goodspeed, Bailouts in a federation, International Tax and Public Finance 2002/9 (4), pp. 409-421.

Vammalle Camilla, Claudia Hulbert, Sub-national Finances and Fiscal Consolidation: Walking on Thin Ice, OECD Regional Development Working Papers 2013/02, OECD Publishing, Paris 2013.

Vammalle Camilla, Rudiger Ahrend, Claudia Hulbert, A Sub-national Perspective on Financing Investment for Growth II - Creating Fiscal Space for Public Investment: The Role of Institutions, OECD Regional Development Working Papers 2014/06, OECD Publishing, Paris.

Wildasin David, Externalities and bailouts: hard and soft budget constraints in intergovernmental fiscal relations, World Bank Policy Research 1997, Working Paper, No. 1843.

Wilson James, A theory of interregional tax competition, Journal of Urban Economics 1986/19 (3), pp. 296-315.

Wójtowicz Kamil, Zalety $i$ wady obowiązującego systemu limitowania deficytu $i$ dtugu samorzadowego w Polsce, Annales Universitatis Mariae Curie-Skłodowska. Sectio H. Oeconomia 2013/47 (2), pp. 153-161.

Wptyw operacji finansowych stosowanych przez wybrane jednostki samorzadu terytorialnego na ich sytuacje finansowa, NIK, Warszawa 2016.

Zodrow George, Mieszkowski Paul, Pigou, Tiebout, property taxation and the under-provision of local public goods, Journal of Urban Economics 1986/19 (3), pp. 356-370.

\section{Statistical data}

Central Statistical Office Dataset, CSO Yearbooks, 1990-2017 editions. 
Joanna DZIAŁO

\title{
INSTYTUCJONALNE LIMITY ZADŁUŻANIA: DOŚWIADCZENIA Z POLSKICH GMIN
}

\author{
(Streszczenie)
}

Zadłużenie to mechanizm finansowy, który umożliwia samorządom lokalnym przesuwanie kosztów bieżących wydatków (w postaci wyższych obciążeń podatkowych) na przyszłe pokolenia. Według teorii finansów publicznych wydatki samorządów lokalnych mogą być nieoptymalne, jeśli decyzje polityków mają na celu osiągnięcie korzyści politycznych. Dlatego potrzeba stosowania ograniczeń dotyczących zadłużania się przez samorządy lokalne jest szeroko argumentowana, a takie ograniczenia obowiązują w większości krajów o zdecentralizowanych finansach publicznych. Niniejszy artykuł analizuje poziom zadłużenia polskich gmin w latach 1990-2017. Głównym jego celem jest przedstawienie dotychczasowych tendencji w polityce przyjętej w Polsce w zakresie obowiązkowych ograniczeń zadłużania się samorządów lokalnych. Ponadto autor podejmuje próbę oceny skuteczności obowiązkowych ograniczeń zadłużania samorządów lokalnych oraz sprawdzenia, czy obecne prawodawstwo uwzględnia teoretyczne argumenty ograniczeń w tym zakresie.

Słowa kluczowe: dług publiczny; zadłużenie samorządów lokalnych; samorządy lokalne; limity długu 